كاربرد سنجش از دور و شبكه عصبى مصنوعى در تخمين غلظت رسوب معلق رودخانه (مطالعه موردى: رودخانه كارون)

زينب ملائى'، جواد ظهيرى "، سعيد جليلى'، محمدرضا انصارى' و ايوب تقىزاده

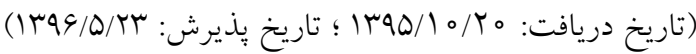

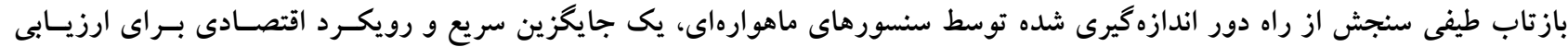

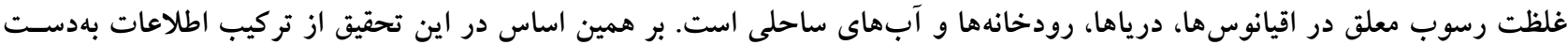

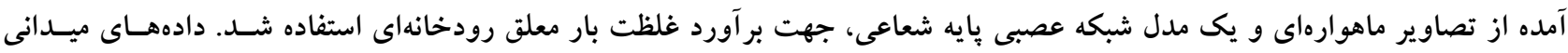

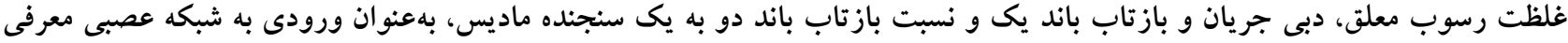

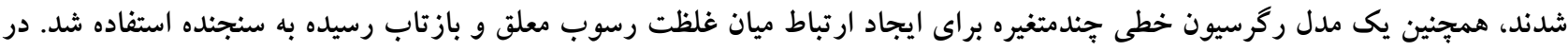

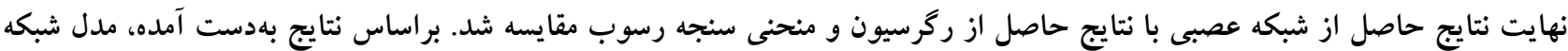

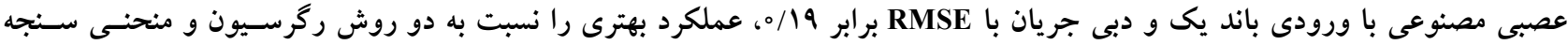

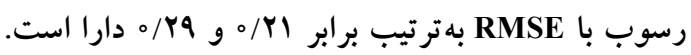

وازههاى كليدى: غلظت رسوب معلق، سنجنده ماديس، شبكه عصبى پايه شعاعى، رگرسيون خطى

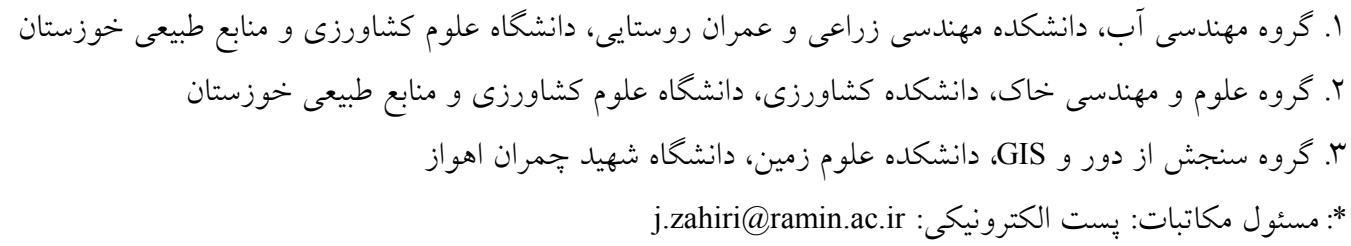


مىشود (9). استفاده از سنجش از دور براى ارزيابى يـارامترهـاى

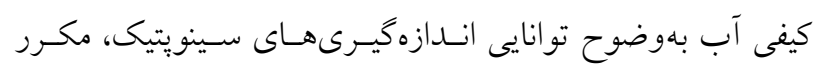

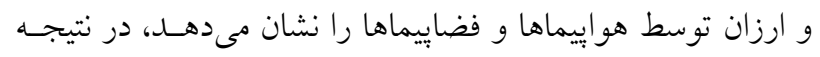

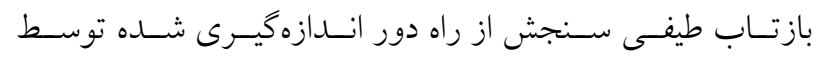

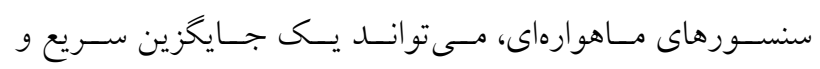

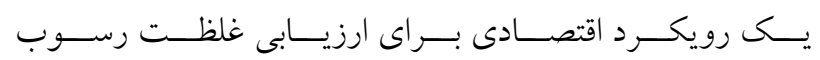

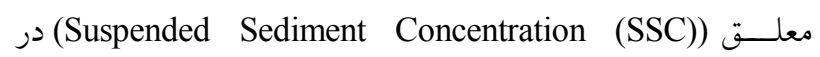

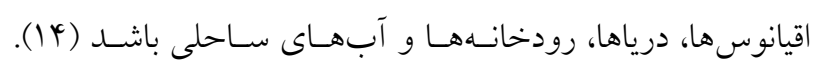

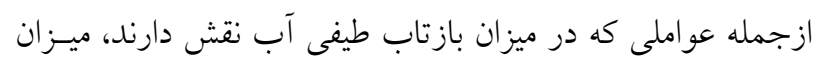

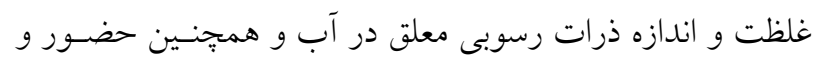

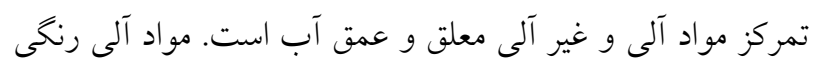

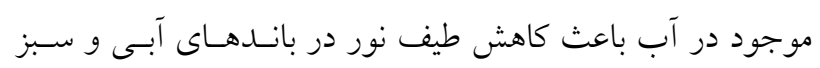

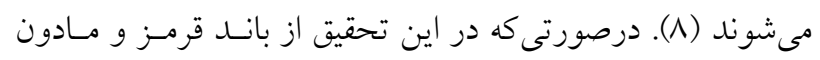

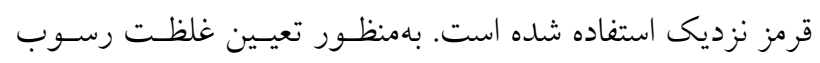

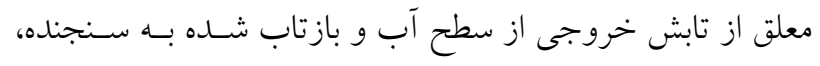

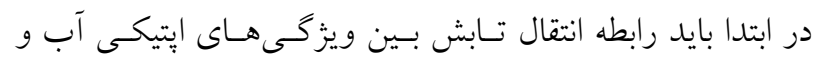

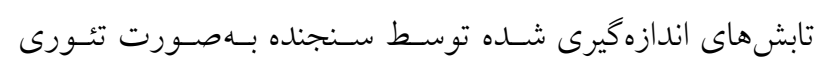

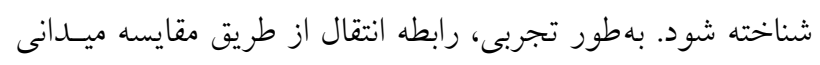

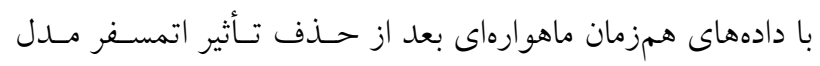

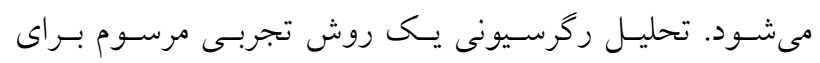

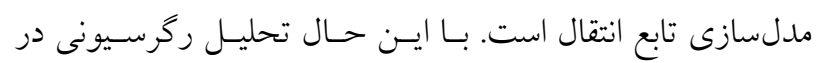

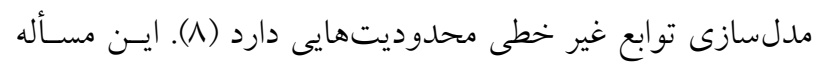

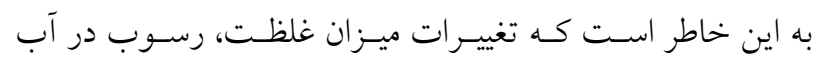

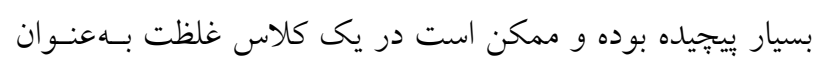

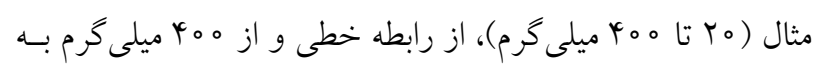

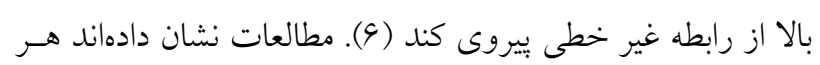

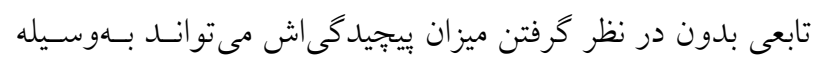

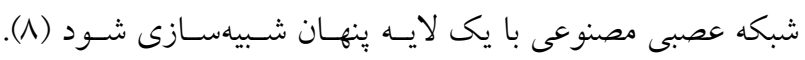

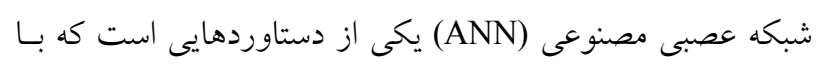

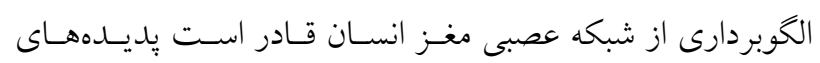

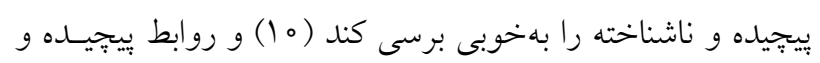

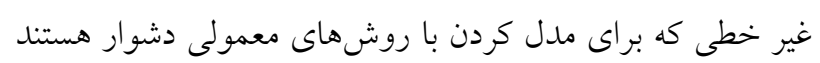

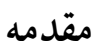

فهم الكوى فرسايش، انتقال و رسوب گذارى يكى عامل بسيار مهم

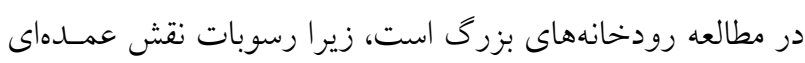

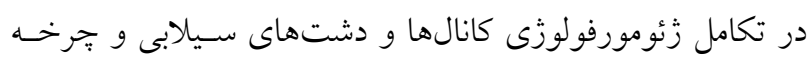

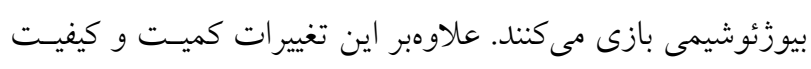

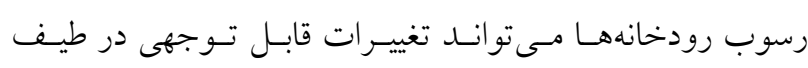

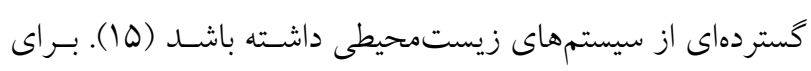

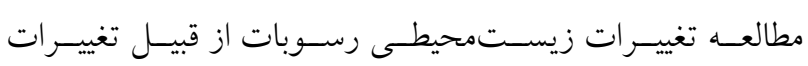

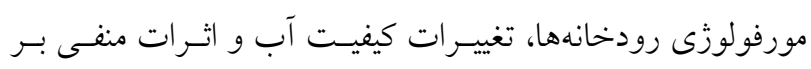

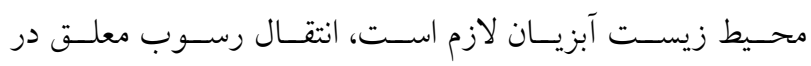

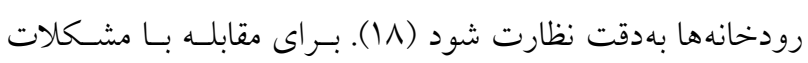

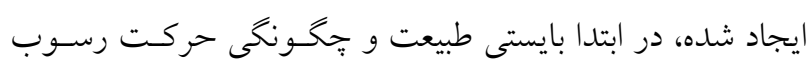

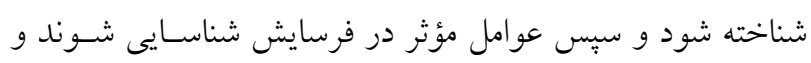

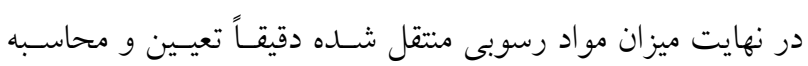
شود تـا بتـوان از آن در طراحسى سـازههـاى آبسى بهـره بــرد (ه).

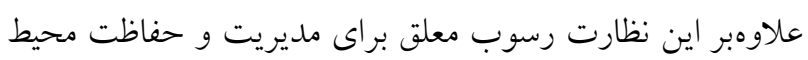

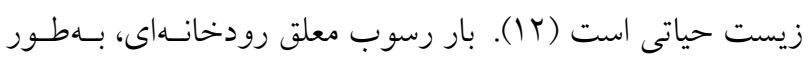

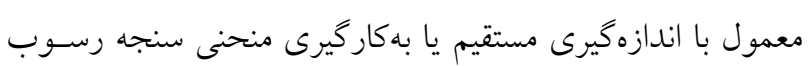

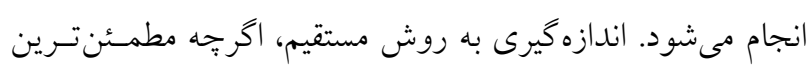

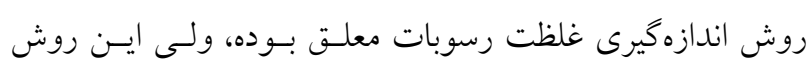

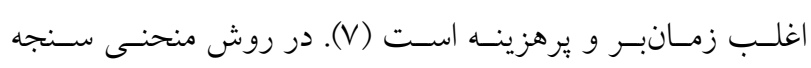

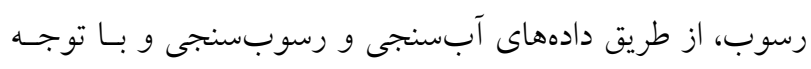

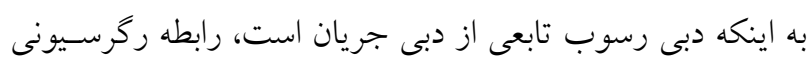

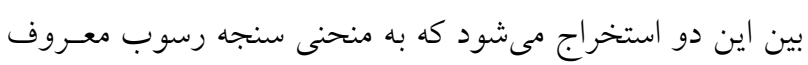

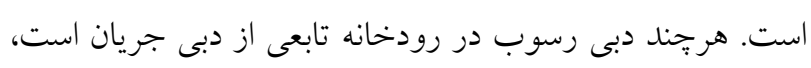

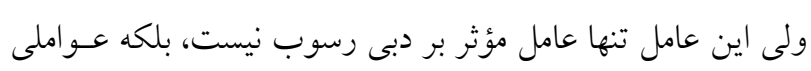

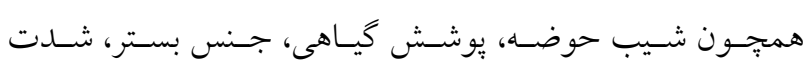

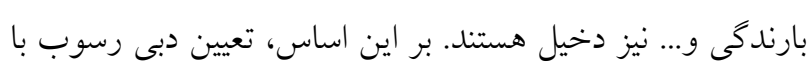

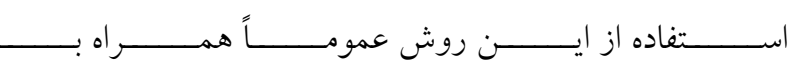

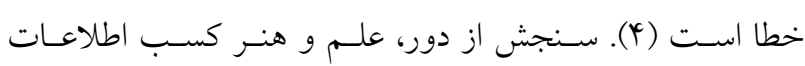

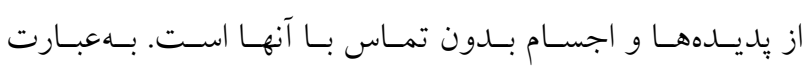

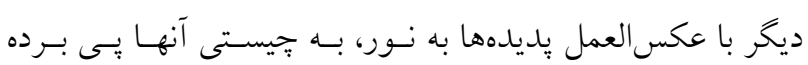


معلق مربوط به ايستخاه آبسنجى اهواز (يكى از ايستخاههـاى

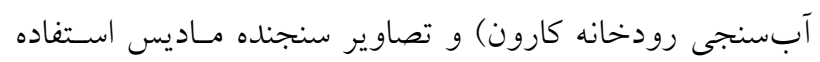

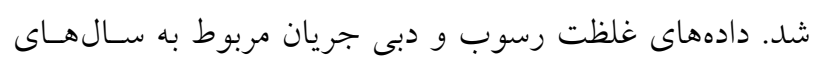

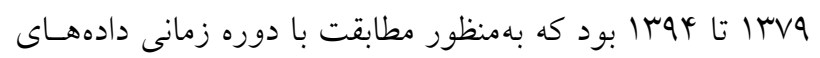

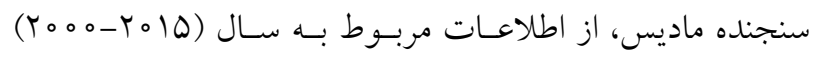

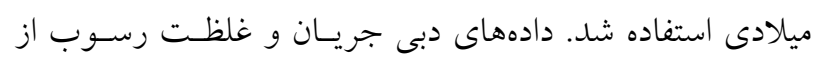

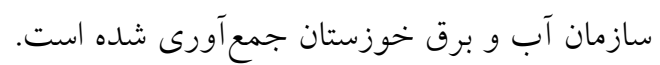

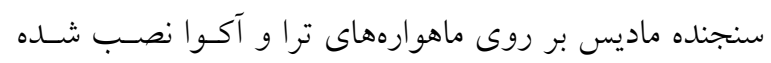

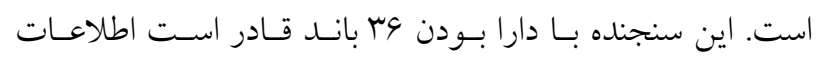

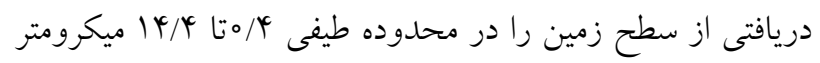

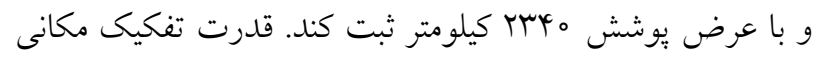

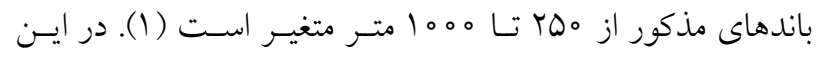

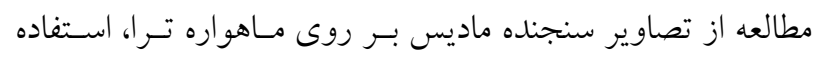

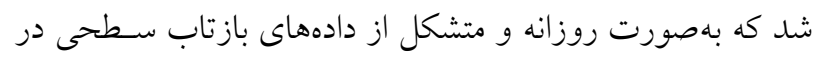

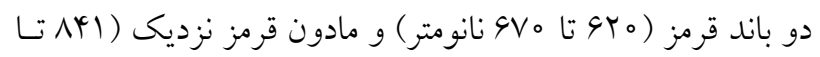

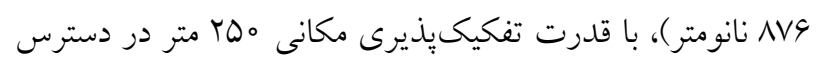

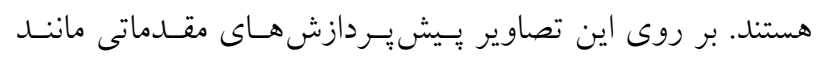

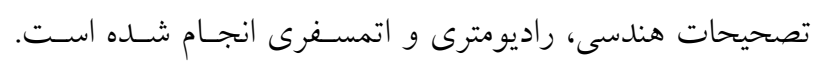
روش معمول تخمين غلظت رسوب معلـق از طريـق سـنجش از راز

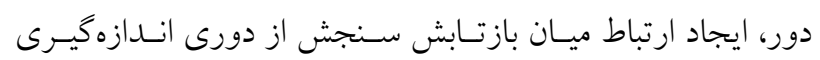

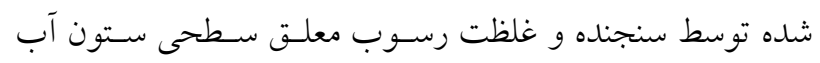

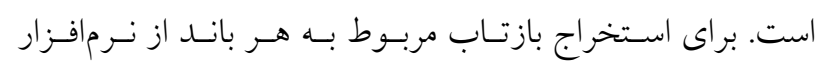

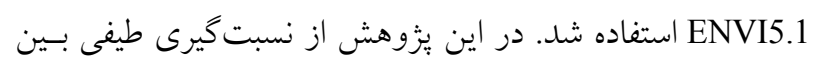

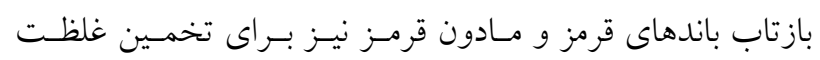

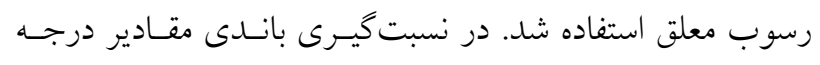

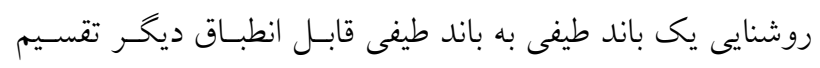

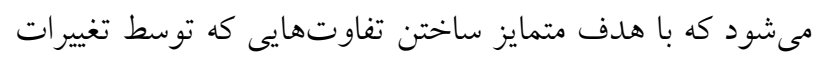

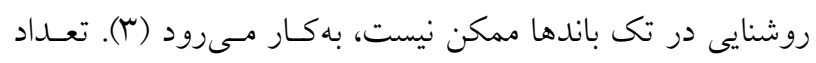

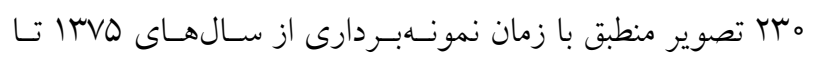

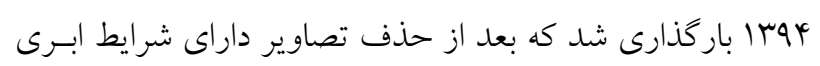

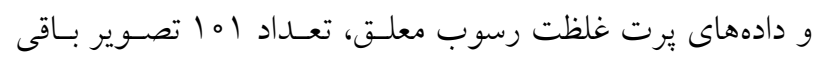
ماند و بررسى شد.
را آموزش دهد (ب ا). ازجمله تحقيقـات صسورت كرفتـه در ايسن

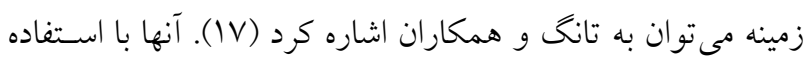

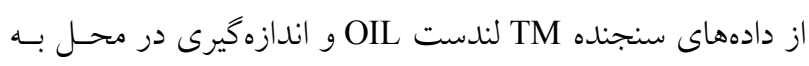
بررسى تغييرات مكانى غلظت رسوب معلـق ناشسى از يـلـ خلـيج Hang Zhoa

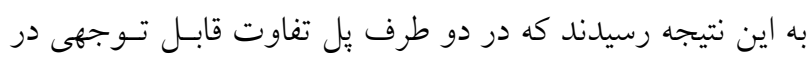

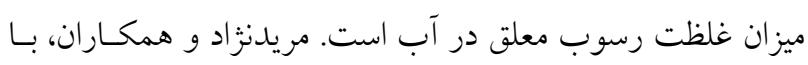

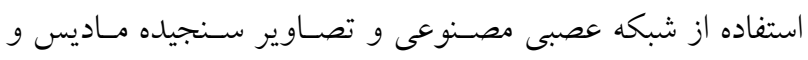

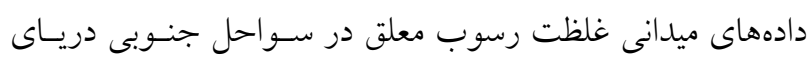

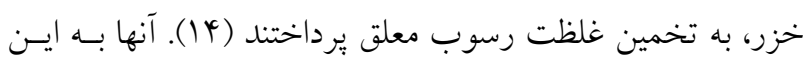

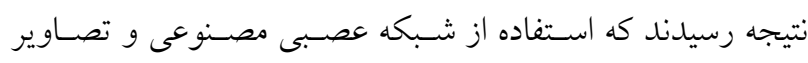

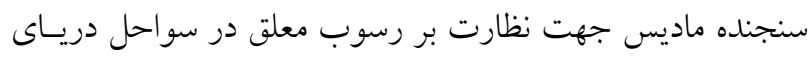

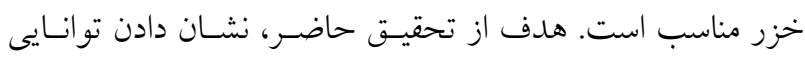

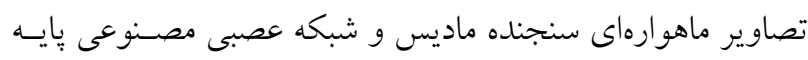

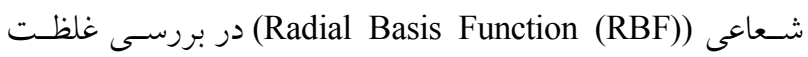

$$
\text { رسوب معلق است. }
$$

\section{مواد و روشها - ماد}

منطقـهـ مـورد مطالعـه رودخانـه كـارون در محــل ايستخاه اهـواز

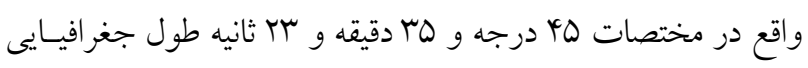

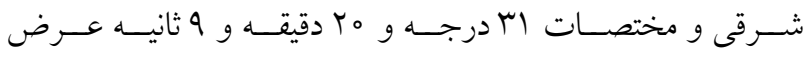

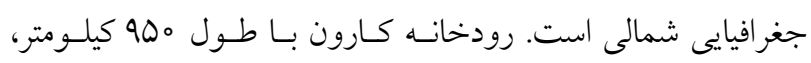

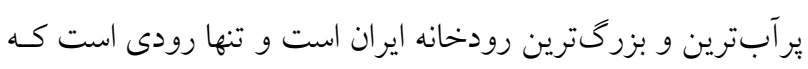

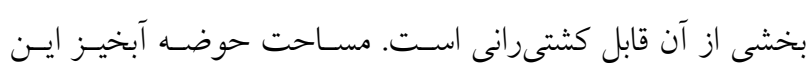

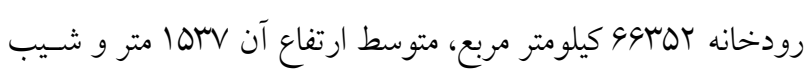

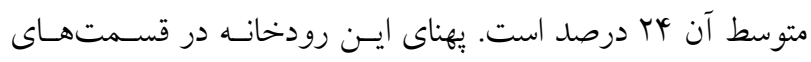

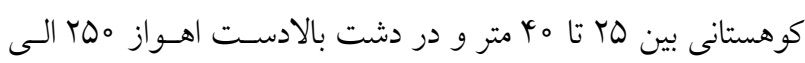

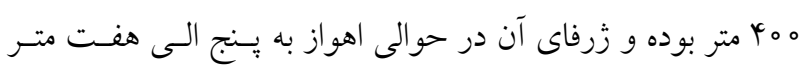
مىرسد.

دادههاى مورد استفاده در اين تحقيق از دادههاى دبى جريان روزانه و غلظـت رسـوبـ 


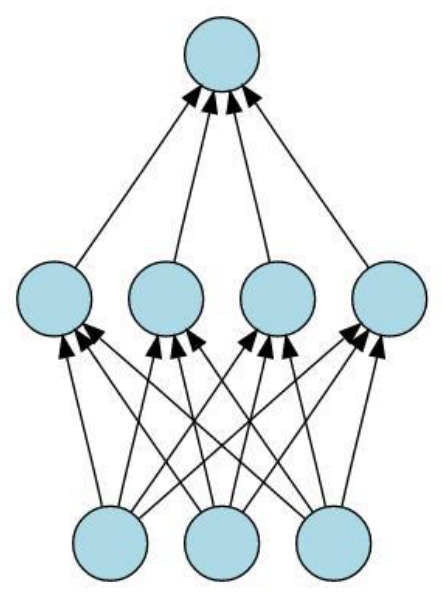

\section{Output y}

\section{Linear weights}

Radial basis

functions

Weights

Input $x$

RBF Rل إختار شبكه

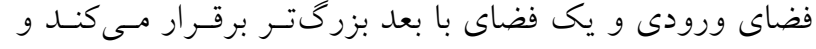

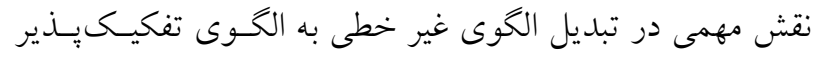

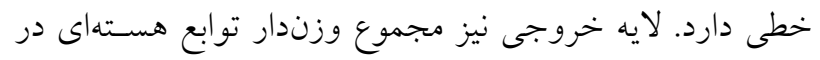
لايه بنهان است كه يك خروجى خطى توليد مى كند. معادله كلى شبكه RBF بهصورت زير است:

$\mathrm{f}(\mathrm{x})=\sum_{\mathrm{i}}^{\mathrm{m}}\left(\mathrm{w}_{\mathrm{i}} \Phi\left\|\mathrm{x}-\mathrm{x}_{\mathrm{i}}\right\|\right)$

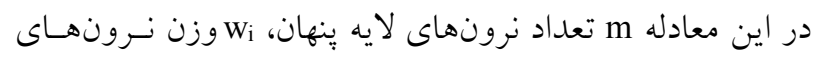

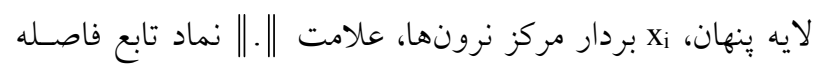

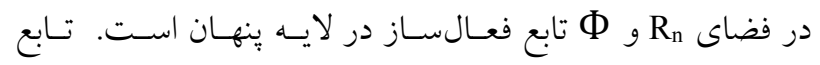

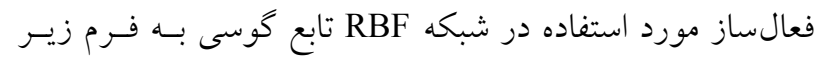

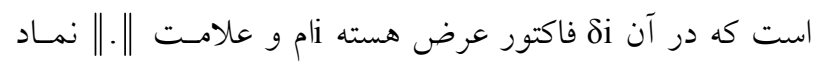
تابع فاصله در فضاى Rn است.

$\Phi\left(\left\|\mathrm{x}-\mathrm{x}_{\mathrm{i}}\right\|\right)=\mathrm{e}^{-\frac{\left\|\mathrm{x}-\mathrm{x}_{\mathrm{i}}\right\|}{\delta_{\mathrm{i}}}}$

بــراى بيــادهسـازى شـبكه RBF از نــــافـزار متلـب اسـتفاده

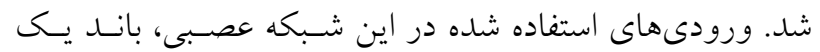

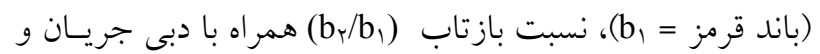

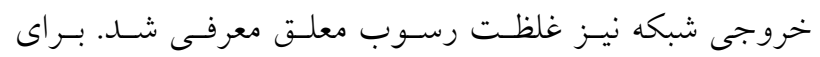

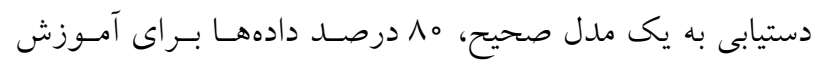

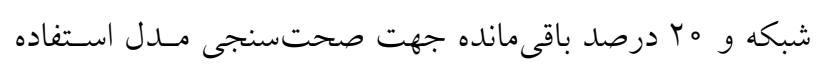

بازبينى دادهها در اين تحقيق ابتدا تصاوير ماهو ارهاى با استفاده از نرمافزارهـاى داى

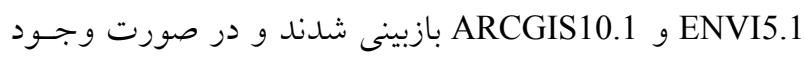

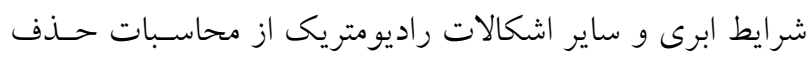

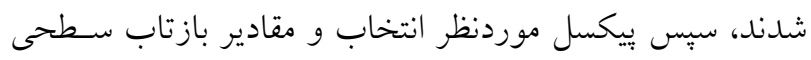

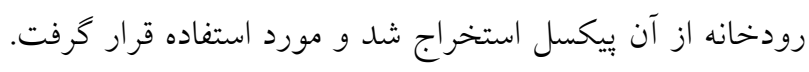

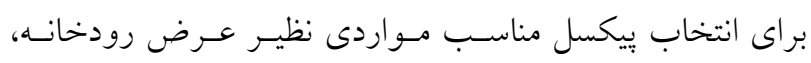

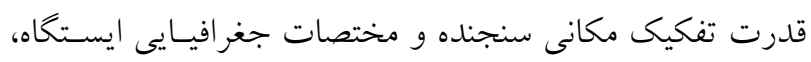

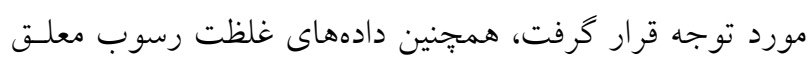

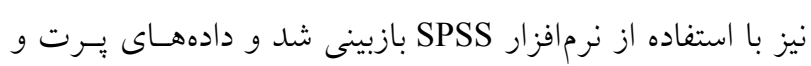

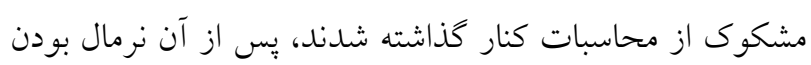

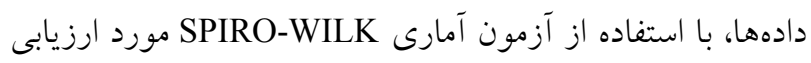

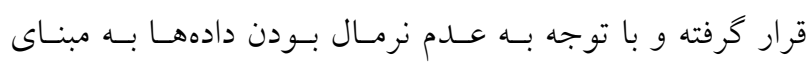
لكاريتم طبيعى تبديل شدند. شبكه عصبى مورد استفاده در اين تحقيق، شبكه RBF بـودهد

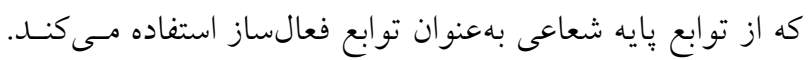

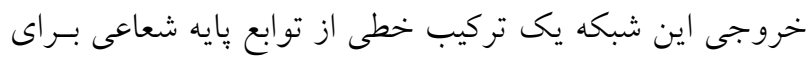
يارامترهاى ورودى نرونها اسـت. سـاختار اصسلى شـبكه RBF

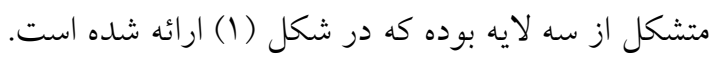
لايه ورودى شامل ورودىىهاى شبكه بوده و در آن هيج كونه

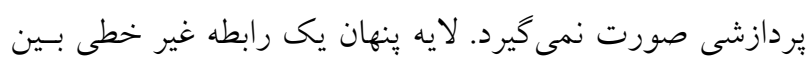


$\mathrm{DR}=\log \frac{\mathrm{SSC}_{\mathrm{pr}}}{\mathrm{SSC}_{\mathrm{me}}}$

$\mathrm{RMSE}=\sqrt{\mathrm{DR}^{r}}$

در روابـط بـالا N تعـداد مشـاهدات، SSCme غلظـت رسـوب مشاهداتى و SSCpr غلظت رسوب محاسباتى است. ضريب R مقدارى بين صفر و يك است كه هرجهه به يك نزديكتر باشـد،

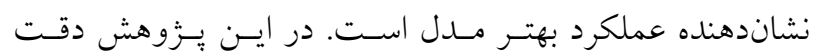

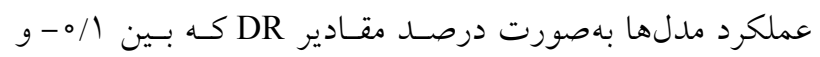

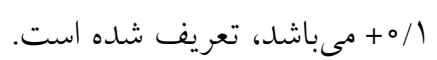

\section{نتايج و بحث}

براى بررسى همبستخى دادهها و معنـادار بـودن آنهـا، تجزيـهـ و تحليل همبستخى بيرسون بين دادههاى SSC و بازتاب بانـدهاى يك و دو سنجنده ماديس، نسبت باندى و دبى جريـان صسورت كرفت. در ابتـدا دادههـاى مربـوط بـه تمـام دورههــا بـهنـــوان ورودى در نظر كرفته شدند كه همبسـتخى يـايينى ميـان مقـادير بازتاب باندى و غلظت واقعى مشاهده شد. بر همين اساس و با توجه به مطالعات كذشته، شـش مـاه اول سـال، بـهـعــوان دوره خشى و شش ماه يايانى سال، بهعنـوان دوره مرطـوب در نظـر كرفته شد. طبق جدول (1) بيشترين همبسـتكى بـراى فصـل مرطـوب ميان SSC با باند يك، نسبت بازتاب و دبى جريان است كـه در

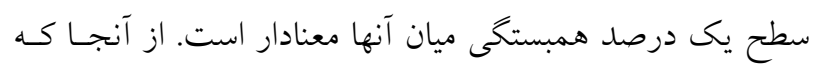
همبستخى ميان باند دو و غلظت رسوب معلق پِايين است، بانـد

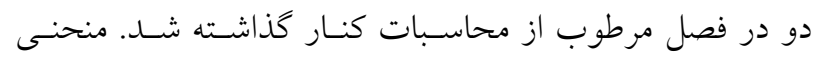
بازتـاب طيفـى آب، كاهشـى عمـومى در بازتـاب را در نتيجـه افزايش طول موج نشـان مسىدهـد، بـهــورىكـهـ در فروسـرخ نزديك، بازتاب آب صاف و عميق مىتواند صـفر فـرض شـود، هرجند بازتاب آب تحت تـأثير حضـور و تمركـز مـواد آلى و غير آلى معلق در آب متفاوت است (Y)، بنابراين جنين استـلال مىشود كه همبستخى يايين ميان غلظت رسوب معلق و بانــد دو

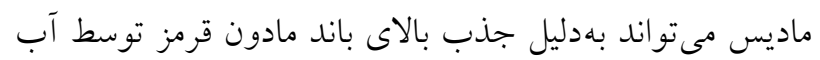

در مدل ركرسيونى ابتدا همبستخى بين انعكـاس آب و دبسى جريان (متغير مستقل) و غلظت رسوب معلق (متغير وابسته) در

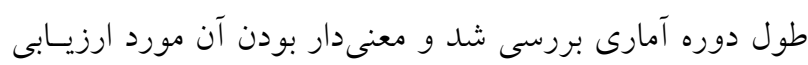

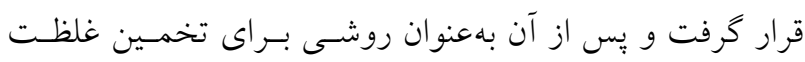

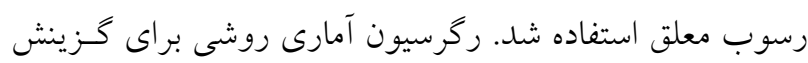

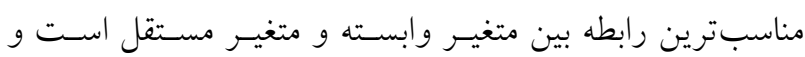
تابعى كه ارتباط بين متغيرهاى مستقل و وابسته را بيان مسىكنـد، تابع ركرسيون ناميده مىشود. در اين تحقيق از نـرمافـزار SPSS جهت يافتن تابع رگرسيون استفاده شد. از متداولترين روشهاى تخمين بار رسـوب معلـق، ايجـاد ارتباط ميان دادههاى دبى رسوب با دبى جريان است. اين رابطـه. منحنى سنجه رسوب ناميده مىشود و شكل كلى آن بـهصورت

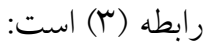

$\mathrm{Q}_{\mathrm{S}}=\mathrm{aQ} \mathrm{w}_{\mathrm{W}}^{\mathrm{b}}$

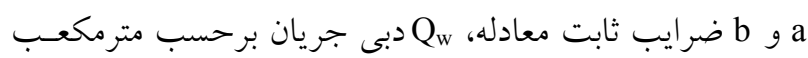
بر ثانيه و Qs دبى رسوب معلق برحسب تـن در روز اسـت و از رابطه (Y) بهدست مى آيد:

$\mathrm{Q}_{\mathrm{s}}=\circ / \circ \wedge \xi \kappa \mathrm{C}_{\mathrm{m}} \mathrm{Q}_{\mathrm{W}}$

در رابطه بالا غلظت رسوب معلق برحسب ميلى گرم بر ليتـر است. مقادير a و b براى رودخانههاى متفاوت از طريـق معادلـه ركرسيون خطى بين للاريتم دبى رسوب و لكاريتم دبى جريـان تعيين مىشود. در اين يزووهش ابتدا بار رسـوب از طريـق روش منحنى سنجه رسوب با استفاده از رابطه شماره (r) بهدست آمد و سبس با استفاده از رابطه (4))، دبى رسوب اندازهگيرى شده به غلظت رسوب معلق، تبديل مىشود.

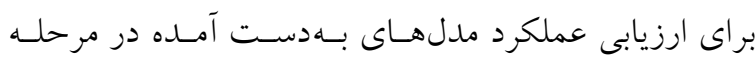

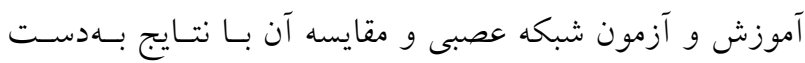

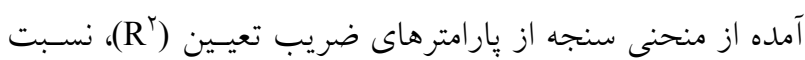
اختلاف (DR) و مجذور ميانخين مربع خطـا (RMSE) اسـتفاده شد. اين بارامترها بهصورت روابط ه، و و Vعريف مىشوند: $\mathrm{R}^{r}=1-\frac{\sum\left(\mathrm{SSC}_{\mathrm{me}}-\overline{\mathrm{SSC}_{\mathrm{pr}}}\right)^{r}}{\sum\left(\mathrm{SSC}_{\mathrm{me}}-\overline{\mathrm{SSC}_{\mathrm{me}}}\right)^{r}}$ 
جدول ا. نتايج تجزيه و تحليل همبستخى بيرسون براى فصل مرطوب

\begin{tabular}{|c|c|c|c|c|c|c|}
\hline $\mathrm{Q}$ & $b T / b l$ & br & b) & $\mathrm{SSC}$ & يارامترهاى آمارى & \\
\hline $0 / 99^{*}$ & $-\circ / \Delta r^{*}$ & $-0 / / V$ & $\circ / 0^{*}$ & $1^{*}$ & ضريب همبستكى ييرسون & \\
\hline$\circ / 000$ & $\% \circ$ & $0 / T V \Lambda$ & $\circ \% 01$ & & ضريب معنادارى & SSC \\
\hline kr & r & r & r & r & تعداد نمونه & \\
\hline
\end{tabular}
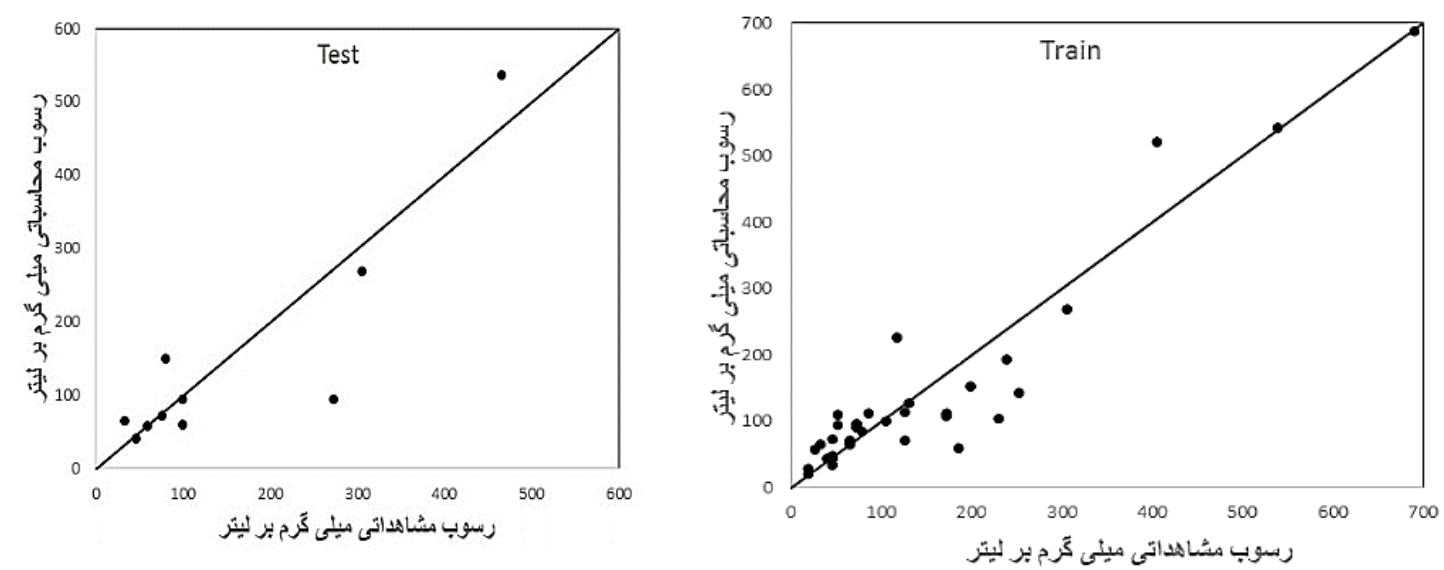

شكل r. همبستخى رسوب مشاهداتى و محاسباتى در مراحل آموزش و صحتسنجى شبكه عصبى (باند يكى و دبى)

بهازاى VIV نرون و براى شبكه عصسبى بِايسه شـعاعى بـا ورودى نسبت باز تاب باند يك به باند دو سنجنده ماديس و دبى جريـان

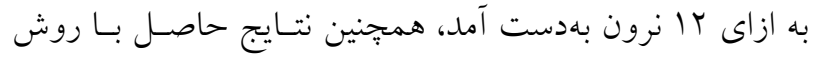

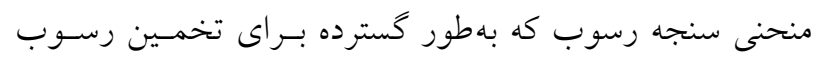

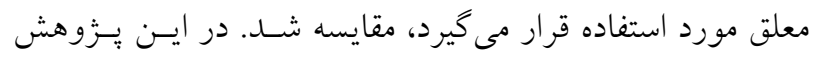

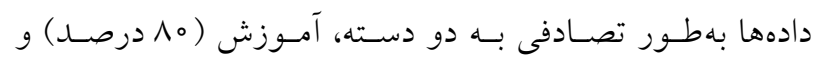

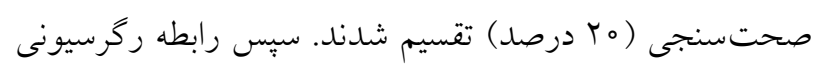

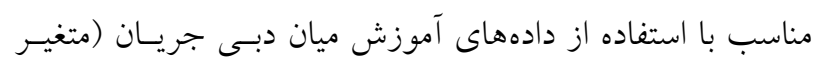

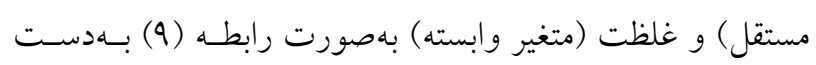

$\mathrm{Q}_{\mathrm{s}}=\circ / \mathrm{v} \mid \vee \wedge \mathrm{Q}_{\mathrm{W}}{ }^{\circ / \wedge r a l}$

سبس رابطه بهدست آمده توسط دادهاى صـحتسـنجى مـورد

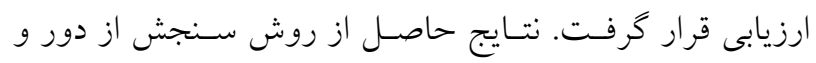
منحنى سنجه رسوب در شكل هاى (Y) تا (ه) آمده است.

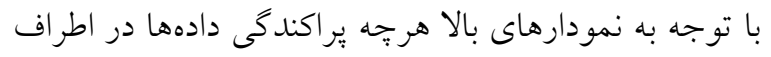

باشد. هنگامى كه غلظت رسوب معلق بهعنوان متغيـر وابسته و باند يكى تصاوير سنجنده ماديس، نسبت بانسـى و دبسى جريـان بلهعنوان متغير مستقل در نظر كرفته شد، رابطه رخرسـيونى ارائسه

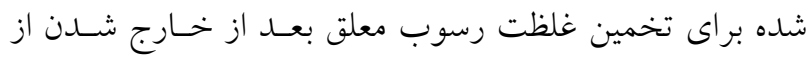
حالت لكاريتمى بهصورت رابطه (^) بهدست آمد: $\mathrm{SSC}=\mathrm{Q}_{\mathrm{W}}{ }^{\circ / \mathrm{ror}^{\circ}} 10^{\mathrm{u}}$

$\mathrm{u}=0 / q \wedge \uparrow+\varphi / / \uparrow \mathrm{b}_{1}-\circ / \wedge r / \frac{\mathrm{b}_{Y}}{\mathrm{~b}_{1}}$

در معمارى شبكه عصبى از يكى شبكه عصبى سه لايه (يكى لايه

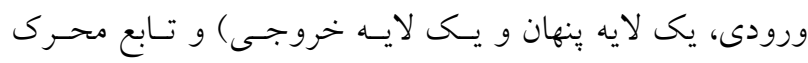

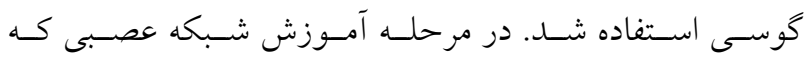

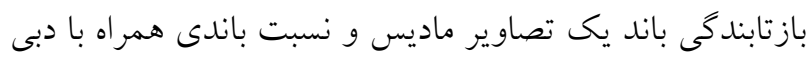
جريان بهعنـوان ورودى شـبكه و غلظـت بـار معلـق بـهــــــان

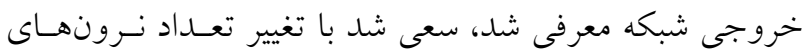

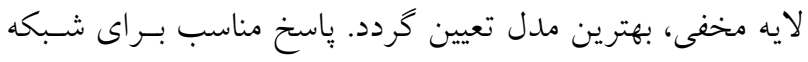

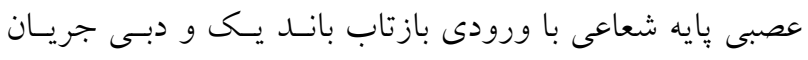



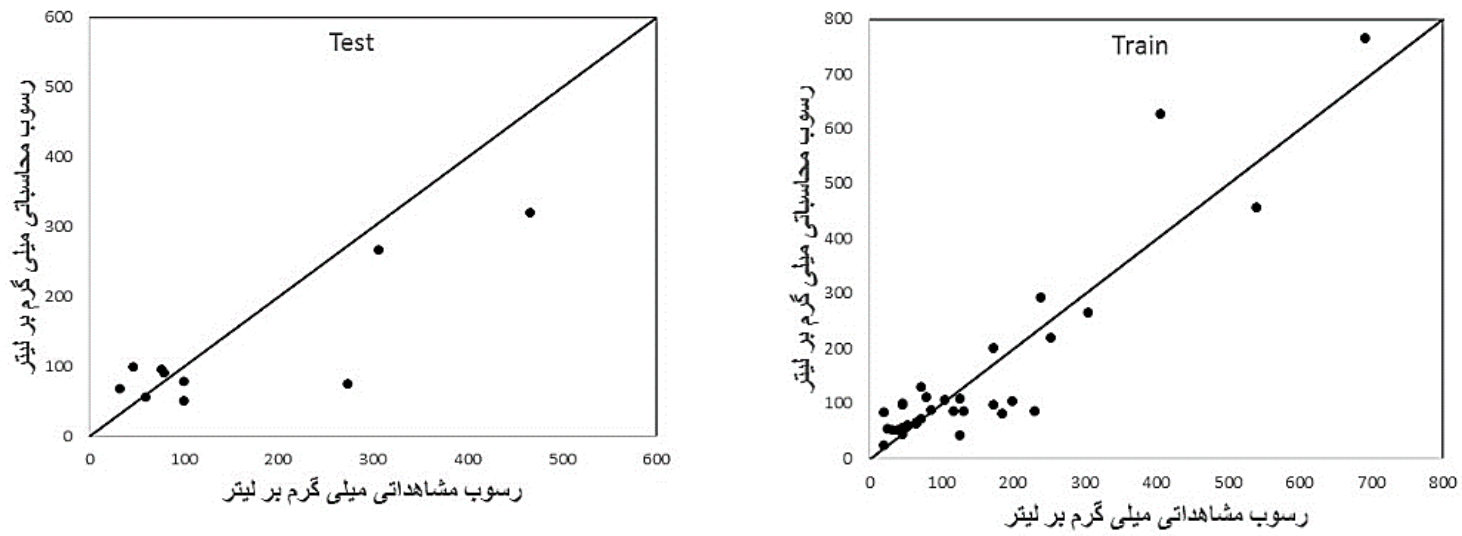

شكل r. همبستخى رسوب مشاهداتى و محاسباتى در مراحل آموزش و صحتسنجى شبكه عصبى (نسبت بازتاب و دبى)
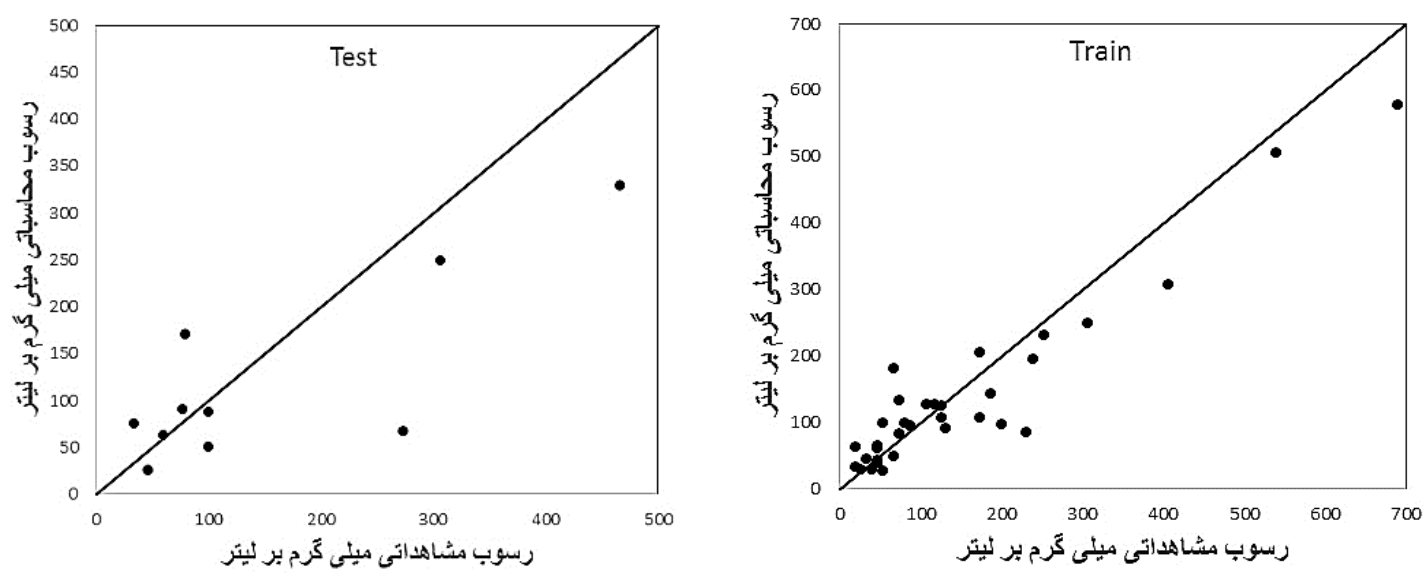

شكل †. همبستخى رسوب مشاهداتى و محاسباتى در مراحل آموزش و صحتسنجى رابطه رگرسيونى
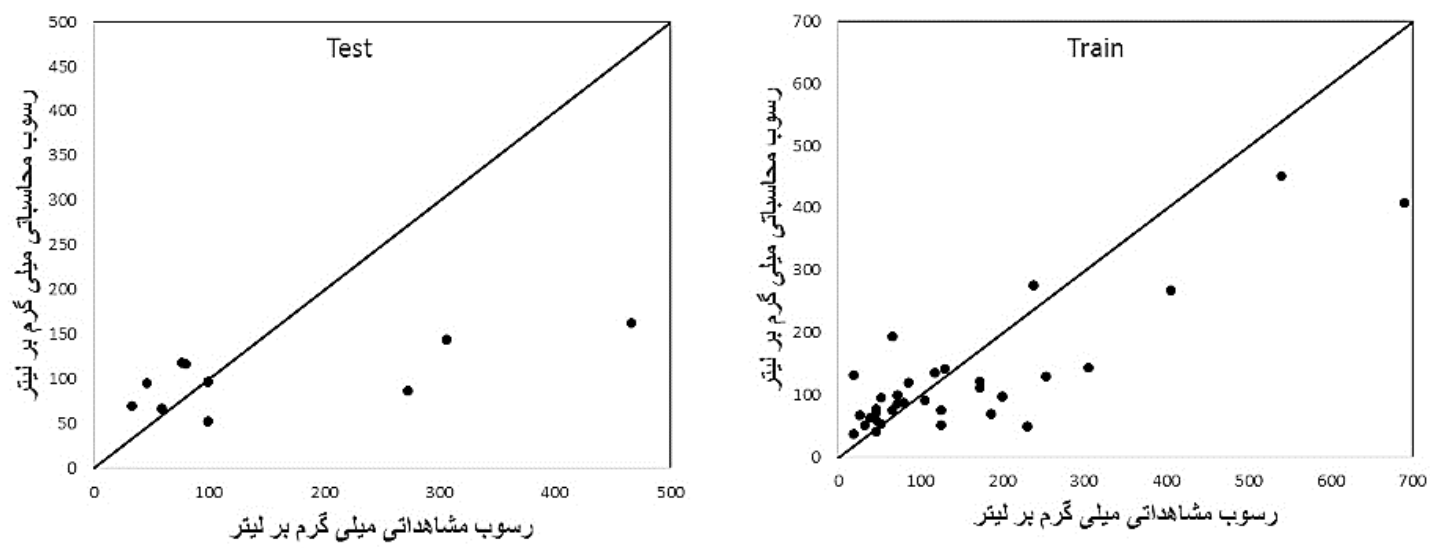

شكل ه. همبستى رسوب مشاهداتى و محاسباتى در مراحل آموزش و صحتسنجى منحنى سنجه رسوب

خط هأ درجه بيشتر است نشاندهنده دقت بالاتر مدل است. بر تصاوير سنجنده ماديس داراى براكندگى بهترى در اطراف خطط

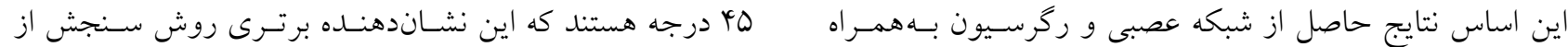




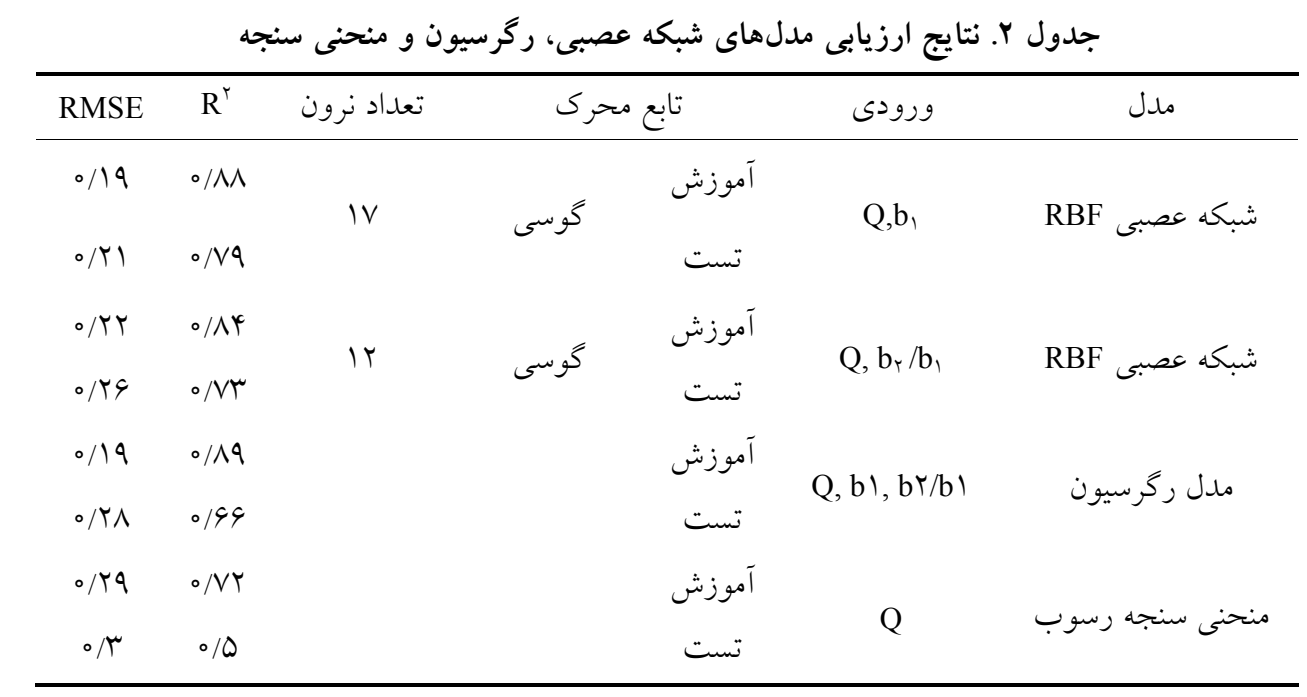

نمونهبردارى از بازتاب نور از سطح آب كه تحت تـأثير غلظـت رسوبات در سطح آب است، استفاده مىشود. در جدول (r) عـلاوهبـر RMSE R R R از ضسريب نسـبت اختلاف (DR) نيز براى براورد دقت مدلها استفاده شده اسـت. در اين جدول، براساس DRF ماى ارائه شده، شبكه عصسبى

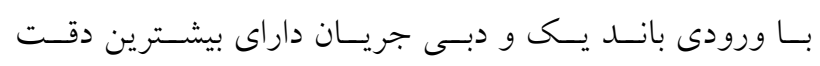

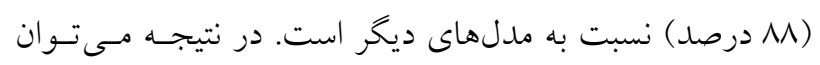
اين مدل را بهعنوان روشى سريع و رويكردى اقتصـادى جهـت تخمين غلظت رسوب معلق معرفى كرد. اين مطالعه با تحقيقات

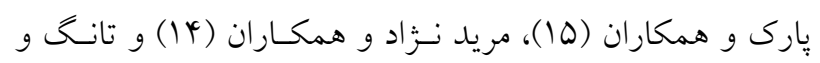
همكاران (IV) كه با استغاده از تصاوير ماهوارهاى به مطالعـه در جهت تخمين غلظت رسوب معلق يرداختند همخوانى دارد. آنها بيان كردند، رابطهاى قوى ميان غلظت رسـوب معلـق و بازتـاب تصاوير ماهوارهاى موجود است. مقادير DR بزركتر از صفر نشاندهنـده درصـدى از مقـادير محاسباتى است كه رسوب را بيشتر از مقادير مشـاهداتى نشـان

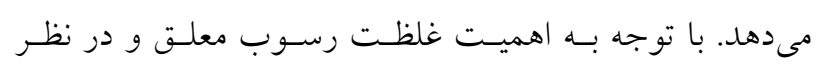
كرفتن ضريب اطمينان جهـت يــروزههـاى مهندسى رودخانسه،

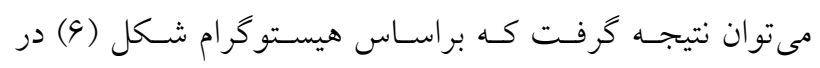
ايستخاه اهواز در مدل منحنى سنجه، مقادير داراى DR بزرگتـر

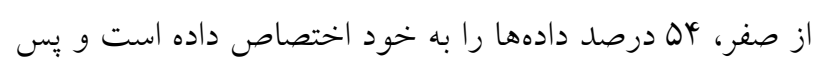
از آن به ترتيب مدل شبكه عصسبى مصسنوعى بـا ورودى نسـبت
دور نسبت به منحنى سنجه رسـوب اسـت. از طـرف ديخـر در برسى نتايج حاصل از شبكه عصبى RBF با دو مدل رگرسيون و

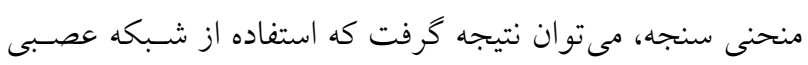
بههمراه تصاوير سنجنده ماديس، در برآورد غلظت رسوب معلق داراى دقت بيشترى نسبت به دو مدل ديخر است.

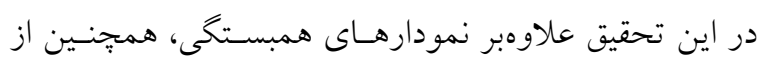
روش تحليل آمارى نيز براى ارزيابى مدلهاى ارائه شده استفاده

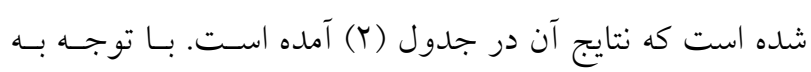
جدول (Y) در ميان مدلهاى شبكه عصبى، مدل با ورودى بانـد

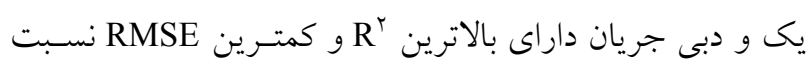
به مدل با ورودى نسبت باندى و دبى است، همجينين در مقايسه نتايج مدلهاى شـبكه عصسبى و روش رگرسـيون هـر دو مــدل شبكه عصبى داراى نتايج بهترى از مدل ركرسيون هستند. دليـل اين امر اين است كه شبكه عصبى مىتواند روابط بِيجيحيده و غيـر خطى غلظت رسوب در رودخانهها را بهتر براورد كند. از طرفى لئي در مقايسه روشهاى سنجش از دور با منحنسى سـنجه مشـاهده مىشود كـه روش منحنسى سـنجه داراى R و RMSE كمتـرى نسبت به اين روشها است كه ايسن نشـاندهنــه برتـرى روش سنجش از دور نسبت به منحنى سنجه است. يكى از دلايل ايسن برترى اين است كه در روش منحنى سنجه فقط از دبسى جريـان در روز نمونــهـــردارى اسـتفاده مسىشـود، درصـورتىكــه در

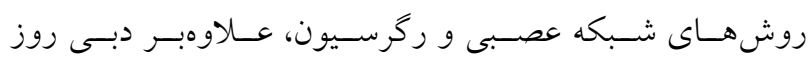


جدول r. نتايج ارزيابى دقت مدلهاى تخمين غلظت معلق رسوب

\begin{tabular}{|c|c|c|c|c|c|c|}
\hline دقت & $\mathrm{DR}>\circ /$ & $\bullet<\mathrm{DR}<0 / \mu$ & $-\circ / \Gamma<\mathrm{DR}<0$ & $\mathrm{DR}<-\circ / \Gamma$ & ورودى & مدل \\
\hline$M$ & $\Delta$ & et & \&V & V & $\mathrm{Q}, \mathrm{bl}$ & شبكه عصبى RBF \\
\hline 19 & ir & rV & kr & 9 & $\mathrm{Q}, \mathrm{br} / \mathrm{bl}$ & شبكه عصبى RBF \\
\hline vq & 9 & ro & py & ir & $\mathrm{Q}, \mathrm{bl}, \mathrm{b} r / \mathrm{bl}$ & مدل رگرسيون \\
\hline V。 & ir & et & rA & 19 & Q & منحنى سنجه رسوب \\
\hline
\end{tabular}

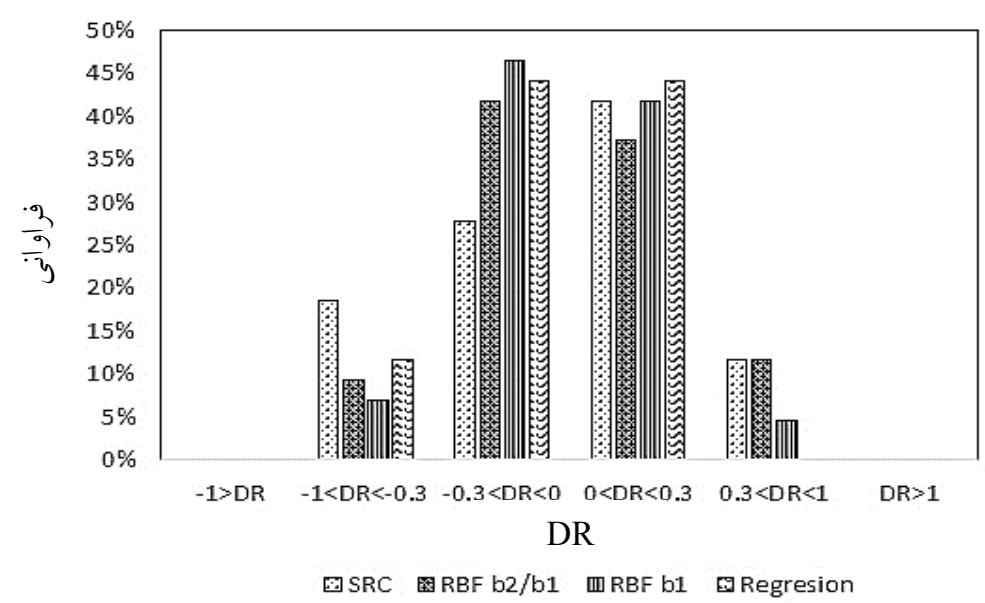

شكل צ. نمودار مقايسه ضريب DR براى مدلهاى مختلف در ايستخاه اهواز

توجه به نتايج بهدست آمده مىتوان مدل شبكه عصبى با ورودى

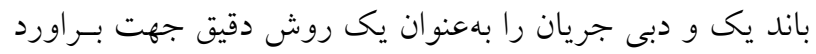

$$
\text { غلظت رسوب معلق معرفى كرد. }
$$

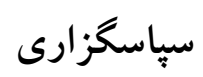

بدينوسيله از سازمان آب و بــرق خوزستـان بـهدليـل كمـك و

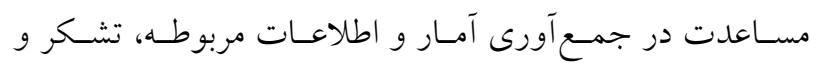

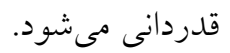

باندى و دبى با بq درصد، مدل شبكه عصبى با ورودى باند يك

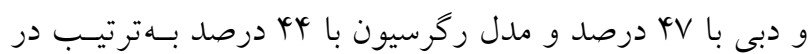

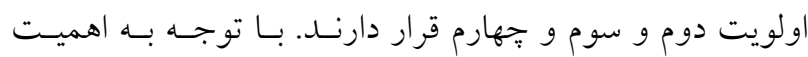
اندازهيرى رسوب در مواقع سيلابى در زمينه مديريت رودخ ونانه

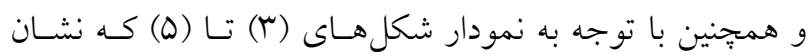
مى دهد، مدل شبكه عصبى با ورودى باند يـك و دبسى جريـان،

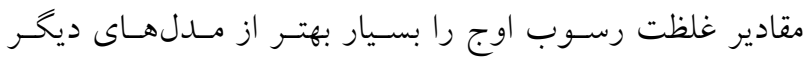

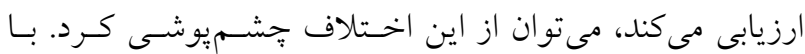

\section{منابع مورد استفاده}

ا. اميدوار، ج.، س. نورى.بوجسا. راهنماى كاربردى نرم/فزارهاى سنجش /ز دور. انتشارات صحرا. مشهد.

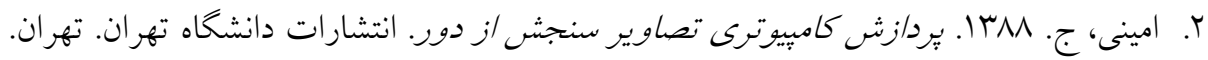

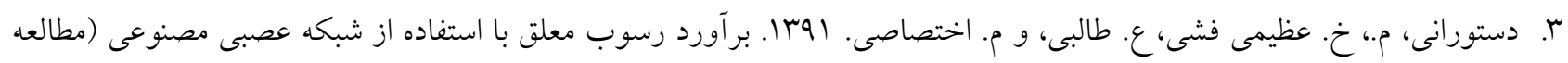

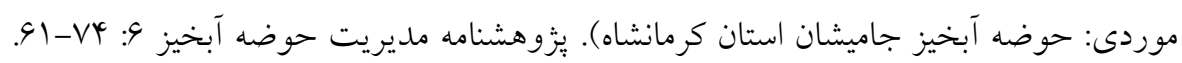

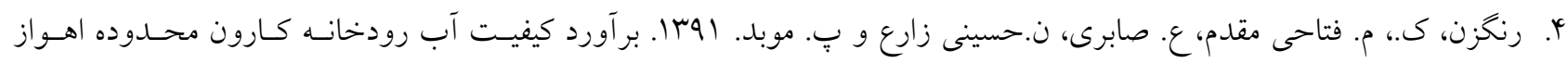




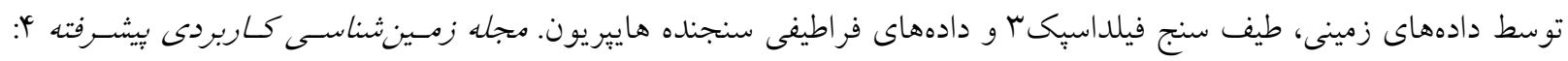

$$
.91-101
$$

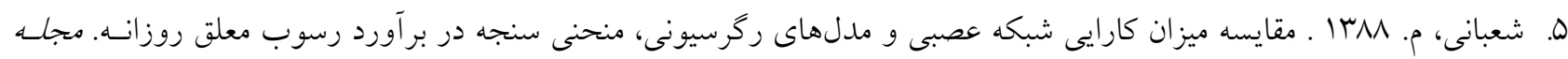

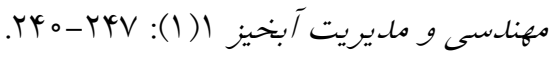

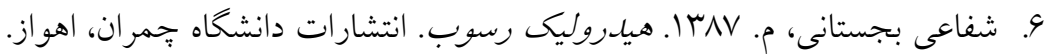

V. صابرى، ك.، آ. بوستانى و س. ر. خداشناس. و^ا؟. استفاده از فن سنجش از دور در يافتن نقاط داراى رسوب در رودخانه. نهمين كنفر انس هيدروليك ايران، دانشخاه تربيت مدرس.

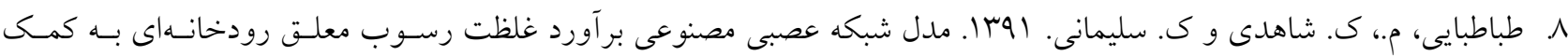
تصاوير سنجنده ماديس (مطالعه موردى ايستخاه هيدرومترى ملاثانى - رودخانه كـارون). نشـريه آب و خـاك (علـوم و صسنايع

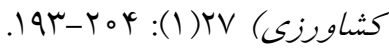

9. كاظمزاده، م.، ع. ايوب زاده وع. مديرنزاد. اوهبا. برآورد غلظت رسوب معلق آبهاى سطحى با غلظت بالا با اسـتفاده از تكنيـى سنجش از دور. ششمين كنخره ملى و نمايشخاه تخصصى مهندسى محيط زيست. تهران. ه ا.معصومى، ح.، س. ر. الوانكار و ف. نجاتى. •وبا. بر آورد رسوب رودخانه با استفاده از امكانات سـنجش از دور. ششـمين كنخــه ملى مهندسى عمر ان، دانشخاه سمنان. سمنان. ا ا. نظرى، م.، ه. قاسميه.، س.ج. ساداتىنزاد و ع. ولى. بوسا. برسى عملكرد شبكه عصبى مصنوعى در مدلسـازى بـارش -روانـاب و مقايسه آن با ركرسيون جنندمتغيره، مطالعه موردى: رودخانه بابل رود. فصلنامه بين/لمللى ثئوهشسى تحليلسى منسابع آب و توسعه

س

12. Jerome, J., R. Bukata and J. Miller. 1996. Remote sensing reflectance and its relationship to optical properties of natural waters. International Remote Sensing 17: 3135-3155.

13. Min, J. E., J. H. Ryu, S. Lee and S. H. Son. 2012. Monitoring of suspended sediment variation using landsat and MODIS in the saemangeum coastal area of Korea. Marine Pollution Bulletin 64: 382-390

14. Moridnejad, A., H. Abdullah and S. K. Alavipanah. 2013. Applying artificial neural networks to estimate suspended sediment concentrations along the southern coast of the Caspian Sea using MODIS images. Arabian Journal of Geosciences 8: 891-901.

15. Park, E. and E. M. Latrubesse. 2014. Modeling suspended sediment distribution patterns of the Amazon River using MODIS data. Remote Sensing of Environment 147: 232-242.

16. Sravanthi, N., I. V. Ramana, P. YunusAli, M. Ashraf, M. M. Ali and A. C. Narayana. 2013. An algorithm for estimating suspended sediment concentrations in the coastal waters of India using remotely sensed reflectance and its application to coastal environments. International Journal of Environmental Research 7(4): 841-850.

17. Tang, D. and C. Yingli. 2015. An Investigation of spatial variation of suspended sediment concentration induced by a bay bridge bused on landsat TM and OLI data. Journal Advances in Space Research 5: 293-303.

18. Wang, J. J. and C. C. Lu. 2009. Estimation of suspended sediment concentrations using terra MODIS: An example from the lower Yangtze revere, china. Journal of science of the Total Environment 408(5): 1131-1138. 


\title{
Estimating Suspended Sediment Concentration Using Remote Sensing and Artificial Neural Network (Case Study: Karun River)
}

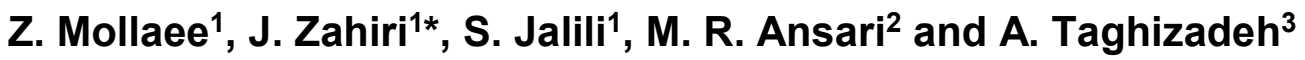

(Received: January 9-2017 ; Accepted: August 14-2017)

\begin{abstract}
Spectral Reflectance of suspended sediment concentration (SSC) remotely sensed by satellite images is an alternative and economically efficient method to measure SSC in inland waters such as rivers and lakes, coastal waters, and oceans. This paper retrieved SSC from satellite remote sensing imagery using radial basis function networks (RBF). In-situ measurement of SSC, water flow data, as well as MODIS band 1 and band ratio of band 2 to 1 were the inputs of the RBF. A multi-regression method was also used to make a relationship between the in-situ data and the water reflectance data retrieved from MODIS bands. The results showed that RBF had the best SSC prediction error (RMSE=0.19), as compared to the multi-regression and sediment rating curve methods, with the RMSE of 0.29 and 0.21 , respectively.
\end{abstract}

Keywords: Suspended sediment concentration, MODIS, RBF, Regression method

1. Department of Water Engineering, Faculty of Agriculture and Rural Engineering, Khuzestan Agricultural Sciences and Natural Resources University, Ahvaz, Iran.

2. Department of Soil Science, Faculty of Agriculture, Khuzestan Agricultural Sciences and Natural Resources University, Ahvaz, Iran.

3. Department of GIS and RS, Faculty of Earth Sciences, Chamran University, Ahvaz, Iran.

*: Corresponding Author, Email: j.zahiri@ramin.ac.ir 